\title{
COMMUNICATIVE ACTIVITIES BASED ON COMPETENCE STANDARD OF 2013 CURRICULUM
}

\author{
Yusna Affandi \\ Email: yusaffandi@live.com \\ MAN Kota Batu
}

\begin{abstract}
For upcoming academic years, senior high schools in Indonesia are implementing a new curriculum, 2013 curriculum. It is stated in the curriculum that English is taught as a language of international communication. Therefore, the English instruction should provide students to enhance their communicative competence. It emphasizes on speaking skill which students acquire for communication. This article proposes three communicative activities based on competence standard of 2013 curriculum to enhance students' communicative competence. The communicative activities are information-gap activities, task completion activities, and information gathering activities. The focus of proposed communicative activities is on improving students' speaking skill.
\end{abstract}

Keywords: 2013 curriculum, communicative activities, speaking skill

\section{INTRODUCTION}

Communicative approach which emerged in 1970 has been a fundamental notion for English language teaching in Indonesia. The approach has seen that teaching English is for communication purposes. Therefore, the focus of the teaching English typically emphasizes in speaking skill. In fact, teaching speaking skill in English in Indonesia has not been a priority for teachers due to some reasons. Teachers are reluctant in speaking English as their classroom language so they prefer their native language, Bahasa Indonesia. Students' lack of vocabularies knowledge is also a consideration for not teaching speaking English as an urgent skill to teach in senior high schools.

English instruction in the class practically tends to be teaching receptive skills only for preparing students to get high scores in national examination, although the syllabus of previous curriculum has been arranged to reach not only receptive skills but also productive skills. The teaching reading and listening is more taken into account by 
teachers. Moreover, teachers insist on teaching grammar in more portion of teaching due to simplicity. Students learn English as grammar-minded language and tend to do merely exercise-based activities rather than communicative competence improvement learning. Thus, they accomplish the activities with no expectation to apply what they have learnt in real life. Whereas, in the worldwide it is expected that students have a good communication skill. Therefore, it is necessarily to put activities which orient to improve speaking ability in order to have good communicative competence. Cahyono and Widiati (2006) argues that classroom activities have a central role in permitting the students communicate and thus enhance their speaking skill. The possible activities are communicative activities. 'Communicative activities' may be more focused on productive skills rather than receptive skills (Richards, 2006).

It is stated that basic competences in 2013 curriculum emphasize that English as international language for communication. The implication is that instructional process should be more focused on mastering communicative competences. Moreover, it can be summarized that standard competences put similar degrees to communicative competences language aspects. Consequently, English instruction for standard competence may be teaching speaking with conducting communicative activity which stimulates students to speak.

This paper is directed to propose three communicative activities in assisting teachers applying basic competences in 2013 curriculum on teaching process. The proposed communicative activities focus on speaking ability which is basic skill in communication. The paper discusses communicative approach notions underlying communicative activities and possible communicative activities to support students enhancing speaking skill for basic competences in 2013 curriculum. This provides a set of activities which includes information gap activities, task completion activities, and information gathering activities.

\section{COMMUNICATIVE ACTIVITIES}

Richards (2006) reviews communicative activities in terms of classroom activities. The activities are based on the principles of 
communicative language teaching. They are accuracy versus fluency activities in which the main focus of both is correctness and natural language use. Then mechanical, meaningful, and communicative practice are about practices which are considered to be sequence. The important one is information gap activity that refers to the fact that in real communication, people normally communicate in order to get information they do not possess. This activity leads some other activities such as jigsaw activity, task-completion activity, informationgathering activity, and so forth.

An important aspect from the activities is that the activities are designed to be carried out in pairs or small groups. It is expected that students take some benefits through the activities. They can learn from hearing the language used by other members of the group. They will produce a greater amount of language than they would use in teacherfronted activities. Their motivational level is likely to increase. They will have the chance to develop fluency. Another aspect is the learners need to expose to authentic materials rather than created materials.

Kumaravadivelu (2006) also reviews the methodological framework of communicative activities used by Littlewood (1981) . The methodological framework consists of pre-communicative activities and communicative activities. In pre-communicative activities, there are structural activities and quasi-communicative activities. In communicative activities, there are functional communication activities and social interaction activities. These categories and sub-categories are in sequence in application.

It is obvious that communicative activities trigger students to be active rather than passive. The role of teachers and students will slightly differ from instruction that focuses on lecturing. It is important to take a note that the role of teachers is initially giving the task to stimulate students to do next activities which students manage by themselves. Griffiths (2001) conclude that the teacher acts as a monitor, a guide, and a facilitator, while the students are the active participants. By closely monitoring the students, teachers are aimed at reducing the class management problem in large classes.

According those theories, there are appropriate communicative activities for teaching English in senior high schools which apply the 
new curriculum consisting communicative standard competences. The classroom activities may be more productive skill such as speaking skill to support students' communicative competence. Therefore, the proposed activities are information gap activity, task completion activity, and information gathering activity. Those activities tend to enhance speaking skill.

\section{Proposed Communicative Activities}

These activities are put into one whole activity based on one of basic competences in 2013 curriculum. The activity can be conducted in one session in sequence. One of basic competence is that students are able to analyze social function, text structures, and linguistics features in descriptive text about people, tourism places, and wellknown historical places according to its contextual uses. Specifically, this activity will accommodate students' skill in comprehending descriptive text and stimulating students to describe well-known places around their living places.

\section{Information-Gap Activity}

The notion of information-gap activities is that the activities refer to the fact of using communication to get information human beings do not possess (Richards, 2006). (Bailey, 2003) asserts that information gap is a useful activity in which one person has information that the other lacks. They must use the target language to share that information. The activity provides an imitated situation to stimulate students to use their target language.

The following is an example of information-gap activities for senior high school students. In this example, the objective of the activity is that students are able to show the directions to a particular or well-known place in target language. The activity is based on the notion of information gap activity and designed based on one of basic competence in 2013 curriculum. This activity is adapted from exercises proposed by (Richards, 2006).

Students are divided into A-B pairs.

The teacher has copied two sets of pictures. One set (for A students) contains a picture of Surabaya Merlion. The other set (for B 
students) contains a picture of Singapore Merlion. There are some slight differences in the pictures.

As an example, teachers can ask two students to come forward and sit back to back while other students watch them. Two students ask questions to try to find out how many differences there are between the two pictures.

After watching the example, students in pair do pair activity in fulfilling the missing information from other students.

This activity leads students to share what information they have in the pictures. By controlled questions or tasks to fulfill, students are eager to find out more information about differences between two statues. It is possible that students are going to talk about the similarities of the statues.

In this activity, students will expose to speak in English when they are asking about the differences of the picture they hold from others. The role of the teacher is a monitor rather than a language feeder. Teacher will supervise students' activity during the process and not give utterances in English in getting information or translate Bahasa Indonesia to English. Students are active in exploring what they should utter in this activity.

The pictures of two statues in different places as authentic materials provide interesting exposure for students. They may imagine that they apply English when they are guiding a native speaker who wants to observe the imitated well-known Singapore statue in Surabaya. Students may feel real things rather than filling the blanks of the similar task type in the book. Authentic materials provide 'real language exposure' to the students (Tamo, 2009) (Guo, 2012) (Polio, 2014).

\section{Task Completion Activity}

Richards (2006) gives an example of task completion activities is map-reading. In map-reading, students have to complete a task which is defined by the teacher. In completing the task students use their target language. Ellis in Nunan (2004) defines that a task is intended to result in language use that allows a similarity, direct or indirect, to the way language is used in the real world. Thus, a task in 
map reading is reflecting how to direct to the target place like in the real situation.

In line with the information gap activity, the following activity leads students to complete a task of reading a map or making a description of directions to the Surabaya Merlion or Singapore Merlion. Due to their advanced knowledge of technology, the students are able to use GPS or Google Maps to help them in writing the directions.

1. Grouping (Teacher provides several sets of 4 pieces cut-pictures of the objects, Teacher spreads the pieces to students, Students have to arrange the pictures into one picture and become a group.) Teacher can use the pictures of the topic.

In their group, students have to write the directions to the object they have in the picture. If a group has Surabaya Merlion, then they have to write down the directions from where they live to the object and so do the other group which get Singapore Merlion. It is possible that students will write how to get there.

2. Switching. In this stage, groups will switch their works to others. Then students in their group will study others' works. Questions for others about the works will be a media to trigger students to speak.

Speaking exposure in this activity will be done after students complete the task in writing the descriptions of directions to go to the objects. By explaining the descriptions to other students, students are learning to express what they have written and get the feedbacks upon what they have done.

\section{Information Gathering Activity}

One of information gathering activities is interviews. Interviews can be conducted by individual or group according to provided time. In this interview section, students are required to collect information about others' knowledge about the objects, Surabaya Merlion and Singapore Merlion. It is possible that information is not merely about the objects but their surroundings. Here the steps in doing interviews as information gathering activity. 
1. After task completion activities in a group and comprehending others' works, students can individually or in a group do interviews about other students' knowledge about the objects.

2. Before doing interview, students can arrange the questions in their previous group, and the teacher provides only initial questions as trigger questions for students to compose.

3. Teacher can set a time and a target for doing interviews so that students will be more active in doing the activity.

4. After doing the activity, students are required to report their findings in front of the class.

\section{CONCLUSION}

Communicative activities are ideas for overcoming the problem in teaching speaking materials based on basic competences in 2013 curriculum. Three proposed communicative activities are suitable for teachers of senior high schools for simplicity and adoptability. Simplicity is that because students are easy to conduct it, and adoptability is that because these activities can be adapted to any basic competences in 2013 curriculum. In these activities, students are far away from silent students. They are active because they involve in interaction to others to get information which triggers them to speak in target language.

\section{REFERENCES}

Bailey, Kathleen M. (2003). Speaking. Practical English Language Teaching. NY: McGraw-Hill Companies, Inc No.

Cahyono, Bambang Yudi, and Widiati, Utami. (2006). The teaching of EFL speaking. Bahasa dan Seni Vol. 34 No. 2.

Griffiths, Aileen. (2001). Implementing Task-Based Instruction to Facilitate Language Learning: Moving Away from Theory. Teflin Journal Vol. 12 No. 1.

Guo, Siao-cing. (2012). Using Authentic Materials for Extensive Reading to Promote English Proficiency. English Language Teaching Vol. 5 No. 8. 
Kumaravadivelu, B. (2006). Understanding Language Teaching From Method To Postmethod. New Jersey: Lawrence Erlbaum Associates Publishers.

Littlewood, William. (1981). Communicative Language Teaching : An Introduction. Cambridge: Cambridge University Press.

Nunan, David. (2004). Task-Based Language Teaching. Cambridge Cambridge University Press.

Polio, Charlene. (2014). Using Authentic Materials in the beginning language classroom. Center For Language Education And Research Vol. 18 No. 1.

Richards, Jack C. (2006). Communicative Language Teaching Today. Cambridge: Cambridge University Press.

Tamo, Daniela. (2009). The Use of Authentic Materials In Classrooms. LCPJ Vol. 2 No. 1. 